Relations industrielles

Industrial Relations

\title{
Bill Ford and David Plowman (Eds), Australian Unions: An Industrial Relations Perspective
}

\section{John Benson}

Volume 46, numéro 4, 1991

URI : https://id.erudit.org/iderudit/050726ar

DOI : https://doi.org/10.7202/050726ar

Aller au sommaire du numéro

Éditeur(s)

Département des relations industrielles de l'Université Laval

ISSN

0034-379X (imprimé)

1703-8138 (numérique)

Découvrir la revue

Citer ce compte rendu

Benson, J. (1991). Compte rendu de [Bill Ford and David Plowman (Eds), Australian Unions: An Industrial Relations Perspective]. Relations industrielles / Industrial Relations, 46(4), 868-869. https://doi.org/10.7202/050726ar

Tous droits réservés @ C Département des relations industrielles de l'Université Laval, 1991
Ce document est protégé par la loi sur le droit d'auteur. L’utilisation des services d'Érudit (y compris la reproduction) est assujettie à sa politique d'utilisation que vous pouvez consulter en ligne.

https://apropos.erudit.org/fr/usagers/politique-dutilisation/ 
Malkiel overly praised Jewish 'girls' and gave little credit to other striking women. Despite these shortcomings, the Diary is still an interesting piece on female working-class life, culture and society, as well as socialist politics in the early twentieth century.

Although it has been written for at least 80 years, in reading the story I found many resemblances to present day women and their concerns, particularly to new immigrants in Canada. The poor working and living conditions of women, the language and cultural barriers of immigrant women in their new country, the exploitation of women in the hands of employers who are often from the same country of origin or ethnic background, the doubleburden of women at paid 'outside' work and the unpaid 'housework' were all too familiar to the 1990s Canada. Overall, both Malkiel's fiction and Basch's essay show that the concerns of women workers have not changed much throughout the years.

Assuming most readers have not heard of the 1909-1910 shirtwaist workers' strike, I would recommend them to read the fiction section first, and then read Basch's analysis. This will enable the readers to learn about the strike and to be able to evaluate the fiction for themselves, prior to reading Basch's thoughtful and thorough analysis. I strongly recommend the book to those interested in the history of labour unions, women workers and socialism in North America, as well as to those interested in the origins of feminism in the U.S.A.

Isik Urla ZeYTinogLU

McMaster University

Australian Unions: An Industrial Relations Perspective, edited by Bill Ford and David Plowman, Australia, Macmillan, 1989, viii +323 p., ISBN 0-333-50208-6 and ISBN 0-333-50206-X (pbk)

In the 1980s Australian trade unions had to confront a rapidly changing economic, social, and industrial environment. The decline in the country's manufacturing base combined with a fall in membership numbers and pressures to shift bargaining towards the enterprise level were some of the factors which forced trade unions to revise their aims, strategies and structures. Australian Unions is therefore a timely addition to the available literature on trade unions, although it should be noted that this publication is the second edition of a book first published in 1983.

The editor's major objectives in compiling the book and selecting topics and papers for inclusion were to provide a multidimensional industrial relations perspective to the study of trade unions and to provide an understanding of the complexities of union structures, processes and behaviour. To achieve these objectives the editors structured the book into four parts: the historical and theoretical context of Australian trade unions; organisation and practice; issues and policy; and future context and perspectives. This structure is similar to that of the first edition although several chapters have been discarded to allow for the inclusion of chapters on union theory, the formation of the present day Australian Council of Trade Unions and issues such as technological change and superannuation. Of the chapters retained some have been updated such as the chapters on workplace unionism (an historical development), and unions and immigrants.

The book, therefore, provides a number of perspectives on trade union organisation and structure in Australia and examines in detail some of the key issues addressed by unions during 
the 1980s. In particular, a number of chapters are worthy of mention. Gardner's chapter on union strategy provides an interesting approach to the understanding of union behaviour. The model is based on the notion of choice rather than determinism in union activity. This choice has definable boundaries and in the formulation of strategy a number of external and internal factors impinge upon the decision making process. For readers interested in a concise description and analysis of union history this is provided in Hagan's chapter on the Australian union movement 1850-1987. Equally, at the micro level Rimmer's chapter on workplace unionism provides a detailed analysis of shop floor union organisation in the period 1917-1987. Several other chapters provide the reader with some of the uniqueness of Australian unions and the issues they pursued in the 1980s. These are Deery's chapter on union aims and methods, Griffin and Giuca's contribution on the formation of one peak labour organisation, Quinlan's interesting and well researched chapter on the relationships between migrants and trade unions, and the chapters on wages policy and technological change by Tiecher and Deery respectively. Thus, for both the student and others interested in Australian unionism the book provides a valuable collection of contemporary readings on selected aspects of Australian trade unions.

Notwithstanding the above, this reviewer has three major criticisms of the book. First, the book is a collection of individual papers with little or no attempt to unite the contributions or to place them within an overall theoretical perspective. The chapter on Strategic Unionsim could have possibly served this purpose but clearly considerably more work is needed in developing a theoretical perspective relevant to Australian Unionism. Second, the book tends to be somewhat dated and whilst individual chapters address a number of issues facing trade unions in the 1980's the book as a whole does not capture the dynamic nature of trade unions during this period. Indeed, a number of important issues such as declining trade union density, the concept of strategic/political unionism, the changing role and growing influence of the Australian Council of Trade Unions, the increasing pace of trade union amalgamations, and the actual operations and influence of trade unionism at the workplace are neglected. Given the shift towards enterprise bargaining during the past four years this last omission is a severe flaw in the book.

Finally, and related in part to the second criticism, the book seems driven, at least to some degree, by issues that are of importance to the Australian Council of Trade Unions. This approach not only neglects issues of importance to individual unions or unions at the workplace, such as the restructuring of the union movement, but it fails to make a critical assessment of the path unionism has taken in Australia and whether such an approach is advantageous for union members.

John BENSON

University of Melbourne

Syndicats, salaires et conjoncture économique, par André Beaucage, Québec, Presses de l'Université du Québec, 1989, 126 pages, ISBN 2-7605-0532-4

L'auteur cherche dans ce volume à analyser l'évolution des politiques sous-tendant les demandes syndicales lors des rondes de négociation entre 1971 et 1983 entre le gouvernement du Québec et le Front commun FTQ-CEQ-CSN. L'approche retenue pour l'analyse est surtout qualitative. Il s'agit d'évaluer «si les grands objectifs des politiques salariales du Front commun se sont traduits dans la réalité, pour l'ensemble de la période 1971-1983, par des résultats compatibles avec l'orientation de ces grands objectifs» (p. 4). 